\title{
SEJARAH PEMIKIRAN EKONOMI ISLAM PERIODE AWAL 450 H/1058 M
}

\author{
Rahmat Zubandi Tahir \\ Sekolah Tinggi Ilmu Syariah Darul Falah Bondowoso \\ email: rahmatzubandidafa@gmail.com
}

\begin{abstract}
Abstrak
Varian dan corak pemikiran ekonomi islam dari para ilmuwan islam menyediakan peta jalan pemberdayaan dan pengembangan ekonomi yang islami. Aktivitas keekonomian masyarakat islam selayaknya merujuk pada konsep ekonomi islam yang telah dibangun oleh para mujtahid. Prinsip-prinsip ekonomi islam secara global telah ada padanan sejarahnya untuk dijadikan dasar perekonomian islam dari hulu sampai hilir. Masyarakat islam hanya butuh kemauan dalam mengimplementasikannya secara nyata dalam kehidupan sehari-hari.

Kata Kunci : Mujtahid
\end{abstract}

\section{A. Pendahuluan}

Manusia merupakan makhluk Allah Swt yang diciptakan dengan bentuk yang sebaikbaiknya, sebagaimana firman Allah dalam surah At-Tin ayat 4 "Sesungguhnya Kami telah menciptakan manusia dalam bentuk yang sebaik-baiknya". Sesuai dengan hakikat wujud manusia dalam kehidupan di dunia, yakni melaksanakan tugas kekhalifahan dalam rangka kepada tuhan. Sebagai khalifah-Nya di bumi, manusia diberi amanah untuk memberdayakan seisi alam raya dengan sebaik-baiknya demi kesejahteraan seluruh makhluk.

Sebagai penyempurna risalah-risalah agama terdahulu, Islam memiliki syariah yang sangat istimewa, yakni bersifat komprehensif dan universal. Komprehensif berarti syariah Islam merangkumseluruh aspek kehidupan, baik ritual ibadah maupun sosial (muamalah), sedangkan universal berarti syariah Islam dapat diterapkan dalam setiap waktu dan tempat sampai hari akhir. 
Berkaitan dengan sumber hukum Islam yakni Al Qur'an dan hadits, dalam kerangka yang sama dengan Alquran, mayoritas hadits nabi juga tidak bersifat absolut, terutama yang berkaitan dengan muamalah. Dengan kata lain, kedua sumber utama hukum islam tersebut hanya memberikan berbagai prinsip dasar yang harus dipegang teguh oleh umat manusia selama hidup di dunia. Adapun untuk merespon perkembangan zaman dan mengatur kehidupan duniawi manusia secara terperinci, Allah Swt. menganugerahi manusia dengan akal pikiran. Dalam hal ini Nabi Saw. bersabda:

"Kamu lebih mengetahui urusan keduniaanmu" (Riwayat Muslim) ${ }^{1}$

Kontribusi kaum muslimin yang sangat besar terhadap kelangsungan dan perkembangan ekonomi pada khususnya dan perdaban dunia pada umumnya, telah diabaikan oleh ilmuan barat. Buku-buku teks ekonomi barat hampir tidak pernah menyebutkan peranan kaum muslimin ini. Sejalan dengan ajaran Islam tentang pemberdayaan akal pikiran dengan tetap berpegang teguh pada Alquran dan hadits Nabi, konsep dan teori dalam Islam pada hakikatnya merupakan respon para cendikiawan muslim terhadap berbagai macam tantangan ekonomi pada waktu tertentu. Ini juga berarti pemikiran ekonomi Islam seusia dengan Islam itu sendiri. ${ }^{2}$ Dibawah ini terdapat beberapa pemikiran tentang ekonomi Islam oleh para tokoh cendikiawan muslim pada masa klasik 450 H/1058 M.

\section{B. Pembahasan}

1. Abu Hanifah (80 H / $699 \mathrm{M})$

\section{a. Biografi Singkat Abu Hanifah}

Abu Hanifah bernama lengkap Nu'man bin Tsabit bin Zauthial- Kufi, dilahirkan pada tahun 80H/699M di Kufah. Kesungguhannya dalam beribadah sejak kecil, berakhlak mulia serta menjauhi perbuatan dosa merupakan bekal hidupnya menjadi orang besar di masa keemasan Islam. Bahkan beliau termasuk orang yang mengukir prestasi keemasan zamannya. Beliau belajar fiqih dari Hammad bin Abi Sulaiman seorang ulama Kuffah pada permulaan abad ke-2. Selain itu beliau juga belajar kepada beberapa ulama tabi'in, seperti Atha bin Abu Rabah dan Nafi' Maula Ibn Umar.

Sebagian besar guru beliau berasal dari madrasah al-ra'yi. Dan ini salah satu yang melatarbelakangi pemikiran hukum Islam beliau sehingga dikenal sebagai ulama fiqih rasionalis yang menjadi rujukan setiap orang yang mendalami hukum Islam.

\footnotetext{
${ }^{1}$ Abu al Husain Muslim bin al Hajjaj al Qusyairi al Naisaburi, Shohih Muslim, (Beirut: Darul Fikr, 1993), jilid 2, 427.

${ }^{2}$ Adiwarman Karim, Sejarah Pemikiran Ekonomi Islam, (Jakarta: PT. Raja Grafindo, 2004), 10.
} 
Abu Hanifah beberapa kali pergi ke Hijaz untuk mendalami fiqh dan hadits. Beliau pernah tinggal di Makkah selama enam tahun pada saat beliau mendapat tekanan politik dari Yazid bin Umar bin Humairah sewaktu menjadik halifah Bani Umayah. Sepeninggal Hammad, majlis Madrasah Kufah sepakat mengangkat Abu Hanifah sebagai kepala Madrasah. Selama itu ia mengabdidan banyak mengeluarkan fatwa dalam masalah fiqh. Fatwa- fatwanya menjadi dasar utama dari pemikiran Madzhab Hanafi yang dikenal sekarang ini.

\section{b. Pemikiran Ekonomi Abu Hanifah}

Abu Hanifah merupakan fuqaha terkenal yang juga seorang pedagang di kota Kufah yang ketika itu merupakan pusat aktivitas perdagangan dan perekonomian yang sedang maju dan berkembang. Semasa hidupnya, salahsatutransaksi yangsangatpopuleradalahsalam,yaitu menjual barangyang akan dikirimkan kemudian sedangkan pembayaran dilakukan secara tunai pada waktu akad disepakati.

Abu Hanifah meragukan keabsahan akad salam tersebut yang dapat mengarah kepada perselisihan. Beliau mencoba menghilangkan perselisihan ini dengan merinci lebih khusus apa yang harus diketahui dan dinyatakan dengan jelas didalam akad, seperti jenis komoditi, mutu, kuantitas serta waktu dan tempat pengiriman. Beliau memberikan persyaratan bahwa komoditi tersebut harus tersedia di pasar selama waktu kontrak dan tanggal pengiriman sehingga kedua belah pihak mengetahui bahwa pengiriman tersebut merupakan sesuatu yang mungkin dapat dilakukan.

Pengalaman dan pengetahuan tentang dunia perdagangan yang didapat langsung Abu Hanifah sangat membantunya dalam menganalisis masalah tersebut. Salah satu kebijakan Abu Hanifah adalah menghilangkan ambiguitas dan perselisihan dalam masalah transaksi. Hal ini merupakan salah satu tujuan syariah dalam hubungannya dengan jual beli. Pengalamannya dibidang perdagangan memungkinkan Abu Hanifah dapat menentukan aturan-aturan yang adil dalam transaksi ini dan transaksi yang sejenis.

Disamping itu, Abu Hanifah mempunyai perhatian yang besar terhadap orang-orang yang lemah. Ia tidak akan membebaskan kewajiban zakat terhadap perhiasan. Sebaliknya, beliau membebaskan pemilik harta yang dililit utang dan tidak sanggup menebusnya dari kewajiban membayar zakat. Beliau juga tidak memperkenankan pembagian hasil panen (muzara'ah) dalam kasus tanah yang tidak menghasilkan 
apapun. Hal ini dilakukan untuk melindungi para penggarap yang umumnya adalah orang- orang yang lemah.

\section{1) Pemikiran tentang Harta Abu Hanifah}

Secara literal harta (al-mal) berarti sesuatu, dimana naluri manusia condong kepadanya. Dalam terminologi fiqh, para imam mazhab memiliki pandangan yang berbeda tentang harta. Abu Hanifah menekankan batasan harta pada term "dapat disimpan". Hal ini mengisyaratkan pengecualian aspek manfaat. Manfaat bukan merupakan bagian dari konsep harta, melainkan konsep milkiyah. Berdasarkan pendapat ini, harta diartikan sebagai sesuatu yang manusia mempunyai keperluan terhadapnya dan dapat disimpan untuk ditasharufkan (digunakan padasaat diperlukan).

\section{2) Pemikiran tentang Riba Abu Hanifah}

Seluruh ulama telah sepakat bahwa riba itu haram. Banyak pandangan yang berbeda dikalangan ulama fiqh mengenai konsep riba. Abu Hanifah membagi riba menjadi dua bagian, yaitu ribafadhl (jaul beli barang sejenis dengan adanya tambahan pada salah satunya) dan ribanasi'ah (menjual barang dengan sejenisnya, tetapi yang satu lebih banyak, dengan pembayaran diakhirkan.

\section{3) Pemikiran tentang PengelolaanUsaha Mudarabah Abu Hanifah}

Salah satu jenis transaksi bagi hasil adalah aqad Mudarabah. Menurut Abu Hanifah, didalam aqad Mudarabah tersebut, pemilik modal boleh ikut bekerja. Kerugian dan keuntungan yang diakibatkan adalah tanggung jawabnya sendiri,pengelola tidak ikut menanggung kerugian dan tetap mendapat bagian hasil atas kerjanya.

Kitab yang dinisbatkan kepada beliau adalah Fiqhal-akbar dan al-'AlimwaalMuta'alim. Kitab yang pertama merupakan kitab fiqih yang komprehensif, karena didalamnya tidak hanya membahas tentang ilmu fiqih ansich, tetapi juga terdapat ilmu aqidah sebagai dasar keimanan danilmu akhlak sebagai ilmu etika Islam.

\section{c. Analisis Terhadap Pemikiran Abu Hanifah}

Abu Hanifah merupakan salah satu tokoh sekaligus fukoha yang dimana pada masa itu sistem perekonomian yang popular adalah menggunakan akad salam. Akad salam ini merupakan akad yang bila terjadi transaksi jual beli, pembayarannya dilakukan di awal akad, sementara barangnya masih dikemudian. Menurut Abu Hanifah, diragukan keabsahan akad salam tersebut yang dapat mengarah kepada perselisihan. Oleh karena 
itu Abu Hanifah berusaha mengubah tradisi akad salam menjadi akad yang bila terjadi transaksi jual beli maka pembayaran dapat dilakukan apabila sudah ada barangnya.

\section{Imam Malik Bin Anas (712 M - 796 M)}

\section{a. Biografi Imam Malik Bin Anas}

Imam Malik bernama lengkap Abu Abdullah Malik bin Anas bin Malik bin Abi Amir bin Amr bin Haris bin Gaiman bin Kutail bin Amr bin Harisal Asbahi, lahir di Madinah pada tahun $712 \mathrm{M}$ dan wafat tahun $796 \mathrm{M}$. Berasal dari keluarga Arab terhormat, berstatus sosial tinggi, baik sebelum maupun sesudah datangnya Islam. Tanah asal leluhurnya adalah Yaman, namun setelah nenek moyangnya menganut Islam, mereka pindah ke Madinah. Kakeknya, Abu Amir, adalah anggota keluarga pertama yang memeluk agama Islam pada tahun $2 \mathrm{H}$. Saat itu, Madinah adalah kota ilmu yang sangat terkenal.

Dalam usia muda, Imam Malik telah menguasai banyak ilmu. Kecintaannya kepada ilmu menjadikan hampir seluruh hidupnya diabdikan dalam dunia pendidikan. Tidak kurang empat khalifah, mulai dari Al Mansur, AlMahdi, Hadi Harun, dan Al Ma'mun, pernah jadi murid Imam Malik. Ulama besar, Imam Abu Hanifah dan Imam Syafi'i pun pernah menimba ilmudari Imam Malik. Belum lagi ilmuwan dan para ahli lainnya. Menurut sebuah riwayat disebutkan murid terkenal Imam Malik mencapai 1.300orang. ${ }^{3}$

\section{b. Pemikiran Ekonomi Imam Malik Bin Anas}

Beliau menerapkan prinsip/azas al-Maslahah al-Mursalah. Al- Maslahah dapat diartikan sebagai azas manfaat (benefit), kegunaan (utility), yakni sesuatu yang memberi manfaat baik kepada individu maupun kepada masyarakat banyak. Sedangkan prinsipal-Mursalah dapat diartikan sebagai prinsip kebebasan, tidak terbatas, atau tidak terikat. Dengan pendekatan kedua azas ini, Malik bin Anas mengakui bahwa pemerintah Islam memiliki hak untuk memungut pajak demi terpenuhinya kebutuhan bersama bila diperlukan melebihi dari jumlah yang ditetapkan secara khusus dalam syari'ah.

\footnotetext{
${ }^{3}$ Fahrur Ulum. 2018. Sejarah Pemikiran Ekonomi Islam, Buku Perkuliahan Program S-1Program Studi Hukum Ekonomi Syariah (Muamalah)Fakultas Syari'ah danHukum UIN Sunan Ampel Surabaya.
} 
Selain itu, beliau juga menggunakan istihsan dalam berbagai masalah, seperti jaminan pekerjaan, menolong pemilik dapur roti dan mesin giling, bayaran kamar mandi bagi semua orang itu sama dan pelaksanaan Qisas harus menghadirkan beberapa orang saksi dan sumpah.

\section{c. Analisis Terhadap Pemikiran Imam Malik Bin Anas}

Imam Malik Bin Anas merupakan tokoh yang menerapkan prinsip /azas al-Maslahah al-Mursalah. Al- Maslahah dapat diartikan sebagai azas manfaat (benefit), kegunaan (utility), yakni sesuatu yang memberi manfaat baik kepada individu maupun kepada masyarakat banyak. Sedangkan prinsipal-Mursalah dapat diartikan sebagai prinsip kebebasan, tidak terbatas, atau tidak terikat.

Dari kedua prinsip tersebut, Malik Bin Anas mendorong pemerintah untuk dapat menarik pajak tanpa batas jika diperlukan, walaupun hal itu melebihi ketentuan yang berlaku. Menurut Imam Malik, hal itu boleh dilakukan oleh pemerintah karena dapat memberikan dampak besar bagi Negara, serta manfaat besar bagi rakyatnya. Semakin kaya suatu Negara, maka semakin mampu pula menjamin kehidupan msyaraktnya.

\section{Abu Yusuf (113 H / 731 M - 182 H / 798 M)}

\section{a. Biografi Abu Yusuf}

Nama lengkap Beliau adalah Ya'qub bin Ibrahim bin Habib Khunais Bin Sa'ad alAnshari al-Jalbi al-Kufi al-Bagdudi, atau lebih dikenal sebagai Abu Yusuf. Dilahirkan di Kufah pada tahun $113 \mathrm{H}(731 \mathrm{M})$ dan meninggal dunia di Baghdad pada tahun $182 \mathrm{H}$ (798 M). Dari nasab ibunya, ia masih mempunyai hubungan darah dengan salah seorang sahabat Rasulullah SAW Sa'ad al-Anshari. Al-Anshori merupakan sebutannya karena dari sisi keturunan ibunya masih ada darah dari kaum Anshar. Beliau dilahirkan di kota Kufah yang terkenal sebagai wilayah Islam yang didominasi oleh ahlu ro'yi. Beliau mendapatkan sebutan al-Kufi karena lahir dan dibesarkan di kota Kufah, sementara alBaghdadi adalah nisbah kepada Baghdad yang merupakan kota tempat beliau mengabdikan dirinya sebagai ulama dan qodhi sekaligus menyebarkan mazhab hanafi hingga akhir hayatnya. ${ }^{4}$

\section{b. Pendidikan dan perjuangan Abu Yusuf}

\footnotetext{
${ }^{4}$ Adiwarman A. Karim, Sejarah Pemikiran Ekonomi Islam, (Jakarta: PT. Raja Grafindo Persada, 2006), Edisi ketiga, 231.
} 
Abu Yusuf menimba berbagai ilmu kepada banyak ulama besar. Sejak kecil Imam Abu Yusuf sudah memiliki minat yang kuat terhadap ilmu terutama ilmu hadits. Beliau meriwayatkan antara lain dari guru-gurunya yaitu Hisyam bin Urwah, Abu Ishaq asySyaibani, Atha' bin Sa'ib dan lain-lain. Dalam fikih beliau belajar kepada Muhammad bin Abdur Rohman bin Abi Laila yang terkenal dengan nama Ibnu Abi Laila. Namun beliau sangat tertarik kepada fikih gurunya dan sekaligus sahabatnya yaitu Imam Abu Hanifah $(150 \mathrm{H})$. Karena ketertarikannya kepada fikih Imam Abu Hanifah yang begitu besar, disamping karena dorongan yang kuat dari Imam Abu Hanifah sendiri, maka beliau terdorong untuk menyebarkan mazhab Hanafi diseluruh wilayah kekuasaan Abbasiyah. Bahkan dapat dikatakan bahwa beliaulah orang pertama dan paling bertanggung jawab terhadap perkembangan fikih Hanafi dikalangan masyarakat Islam. Hal ini dikarenakan beliau diangkat menjadi Ketua hakim (Qadhi alQudhah) oleh Khalifah Harun ar-Rasyid. ${ }^{5}$

Selama tujuh belas tahun Abu Yusuf tiada henti-hentinya belajar kepada pendiri mazhab Hanafi tersebut. Ia pun terkenal sebagai salah satu murid terkemuka Abu Hanifah. Sepeninggal gurunya Abu Yusuf bernama Muhammad bin al-Hasan al-Syaibani menjadi tokoh pelopor dalam menyebarkan dan mengembangkan mazhab Hanafi.

\section{c. Pemikiran Ekonomi Abu Yusuf}

Menurut Abu Yusuf sistem Ekonomi Islam seharusnya mengikuti prinsip mekanisme pasar dengan memberikan kebebasan yang optimal bagi para pelaku di dalamnya, yaitu produsen dan konsumen. Dalam konsep ekonomi Islam penentuan harga dilakukan oleh kekuatan-kekuatan pasar, yaitu kekuatan permintaan dan kekuatan penawaran. Dalam konsep Islam, pertemuan permintaan dengan penawaran tersebut haruslah terjadi secara rela sama rela, tidak ada pihak yang merasa terpaksa untuk melakukan transaksi pada tingkat harga tersebut.

Abu Yusuf dalam kitab Al-Kharaj bahwa mahal atau murahnya suatu komoditas tidak bisa ditentukan secara pasti, dimana murah bukan karena melimpahnya barang tersebut dan mahal bukan karena kelangkaannya. ${ }^{6}$ Hal ini dinyatakan melalui statement beliau

\footnotetext{
${ }^{5}$ Suprehaten, Pemikiran Abu Yusuf Tentang Pasar Dalam Kitab Al-Kharaj, (Skripsi, UIN Syarif Kasim, Riau, 2010), 20.

${ }^{6}$ Mustafa Edwin Nasution, ,167.
} 
"mahal dan murah merupakan ketentuan Allah, terkadang makanan melimpah tetapi harga mahal dan terkadang makanan sedikit tapi tetap murah". 7

\section{d. Analisis Terhadap Pemikiran Abu Yusuf}

Pemikiran ekonomi Abu Yusuf sangatlah sederhana, beliau berpendapat bahwa mekanisme yang terjadi di pasar bukanlah disebabkan karena satu orang atau satu kelompok orang. Haga mahal belum tentu diakibatkan karena barang yang langka, serta harga murah juga belum tentu karena barang yang melimpah. Melainkan hal tersebut merupakan semata kehandak dari Allah sang pengatur segala yang ada di alam semesta.

\section{Al Syaibani (132 H / 750 M)}

\section{a. Biografi Al Syaibani}

Abu Abdillah Muhammad bin al-Hasan bin Farqad Al-Syaibani lahir pada tahun $132 \mathrm{H}$ (750 M) di kota Wasith, ibu kota Iraq pada masa akhir pemerintahan bani Umawiyyah. Ayahnya berasal dari negeri Syaiban di wilayah jazirah Arab. Dalam menuntut ilmu, Al Syaibani tidak hanya berinteraksi dengan para ulama ahli ra'yi, tetapi juga ulama yang ahli hadits. Layaknya ulama terdahulu, ia juga berkelana keberbagai tempat untuk menuntut ilmu. ${ }^{8}$

Setelah memperoleh ilmu yang memadai, Al Syaibani kembali ke Baghdad yang pada saat itu dalam kekuasaan bani abbasiyah. Ia mempunyai peranan penting dalam majelis ulama dan kerap kali didatangi oleh pencari ilmu. Hal tersebut semakin mempermudah Al Syaibani dalam mengembangkan madzhab hanafi, apalagi ditunjang kebijaan pemerintah yang pada saat itu menetapkan madzhab hanafi sebaga madzhab negara.

\section{b. Pemikiran Ekonomi Al Syaibani}

Dalam mengungkapkan pemikiran ekonomi Al Syaibani, para ekonom muslim banyak merujuk pada kitab al kasb, sebuah kitab yang lahir sebagai respon penulis terhadap sikap zuhud yang tumbuh dan berkembang pada abad kedua hijriyah. Secara keseluruhan kitab ini mengemukakan kajian mikroekonomi yang berkisar pada teori kasbi (pendapatan) dan sumber-sumbernya serta pedoman perilaku dan konsumsi.kitab tersebut merupak kitab pertama dalam Islam yang membahas permasalahan ini. ${ }^{9}$ Oleh sebab itu, tidak berlebihan jika Dr. Al Janidal menyebut Al Syaibani sebagai salah seorang perintis ilmu ekonomi dalam Islam.

\footnotetext{
${ }^{7}$ Suprehaten, "Pemikiran Abu Yusuf...", 44.

${ }^{8}$ Karim, Sejarah Pemikiran, 233.

${ }^{9}$ Ibid, 234.
} 
Al Syaibani mendefinisikan al-kasb (kerja) sebagai mencari perolehan harta melalui berbagai cara yang halal. Dalam ilmu ekonomi, hal yang demikian disebut dengan aktivitas produksi. Dengan demikian, maka pendapat Al Syaibani menjelaskan bahwa aktifitas produksi dalam Islam berbeda dengan aktifitas produksi dalam ekonomi konvensional. Dalam Islam tidak semua aktifitas yang menghasilkan barang atau jasa disebut produksi, sebab aktifitas tersebut sangat berkatan erat dengan halal haramnya suatu barang atau jasa serta cara memperolehnya. Artinya bahwa, hanya aktifitas menghasilkan barang atau jasa yang halal saja yang dapat disebut sebagai aktifitas produksi. Produksi barang atau jasa sebagaimana dinyatakan dalam ilmu ekonomi, dlakukan sebab barang atau jasa tersebut mempunyai nilai kegunaan (utilitas), dan Islam memandang bahwa suatu barang atau jasa dapat memiliki nilai guna (utilitas) apabila mengandung nilai kemaslahatan.

Dari uraian diatas, nampak jelas bahwa orientasi bekerja dalam pandangan Al Syaibani adalah hidup untuk meraih keridlaan Allah Swt. disisi lain, kerja memang merupakan usaha untuk mengaktifkan roda perekonomian, termasuk proses produksi, konsumsi, dan distribusi, yang secara makro mempunyai dampak pada pertumbuhan perekonomian negara. Dengan demikian, kerja mempunyai peranan yang sangat penting dalam memenuhi hak Allah Swt., hak hidup, keluarga, dan masyarakat.

Dalam pengklasifikasian usaha-usaha perekonomian Al Syaibani membagi menjadi empat macam, yaitu sewa menyewa, perdangan, pertanian, dan perindustrian. Sedangkan para ekonom kontemporer membagi menjadi tiga macam, yaitu pertanian, perindustrian, dan jasa. Diantara keempat jenis usaha perekonomian tersebut, Al Syaibani lebih memprioritaskan pada pertanian, sebab menurutnya pertanian memproduksi kebutuhan dasar manusia yang sangat menunjang dalam melaksanakan kewajiban.

\section{c. Analisis Terhadap Pemikiran Al Syaibani}

Al Syibani merupakan salah satu tokoh yang terkenal dengan kezuhudannya. Al Syaibani mendefinisikan al-kasb (kerja) sebagai mencari perolehan harta melalui berbagai cara yang halal. Dalam ilmu ekonomi, hal yang demikian disebut dengan aktivitas produksi. Dengan demikian, maka pendapat Al Syaibani menjelaskan bahwa aktifitas produksi dalam Islam berbeda dengan aktifitas produksi dalam ekonomi konvensional. Dalam Islam tidak semua aktifitas yang menghasilkan barang atau jasa 
disebut produksi, sebab aktifitas tersebut sangat berkatan erat dengan halal haramnya suatu barang atau jasa serta cara memperolehnya. Artinya bahwa, hanya aktifitas menghasilkan barang atau jasa yang halal saja yang dapat disebut sebagai aktifitas produksi. Produksi barang atau jasa sebagaimana dinyatakan dalam ilmu ekonomi, dlakukan sebab barang atau jasa tersebut mempunyai nilai kegunaan (utilitas), dan Islam memandang bahwa suatu barang atau jasa dapat memiliki nilai guna (utilitas) apabila mengandung nilai kemaslahatan.

\section{Abu Ubaid (150 H)}

\section{a. Biorafi Abu Ubaid}

Abu Ubaid bernama lengkap al Qasim bin Sallam bin Miskin bin Zaid al Harawi al Azadi al Baghdadi. Lahir pada tahun 150 hijriyah di kota Harrah, Khurasan, sebelah barat laut Afghanistan. Ayahnya keturunan Byzantium yang menjadi maula suku Azad. ${ }^{10}$

Ia mempelajari banyak cabang keilmuan, diantaranya tata bahasa Arab, tafsir, hadith, fiqh, qiraat. Pada tahun 192 H, Tsabit ibn Nasr ibn Malik, gubernur Tughur dimasa khalifah Harun ar Rasyid mengangkat Abu Ubaid sebagai Qadhi (hakim) di Tarsus hingga tahun 210 H. Setelah itu ia tinggal di Baghdad selama 10 tahun. Pada tahun 219 $\mathrm{H}$, setelah menunaikan ibadah haji ia menetap di Makkah sampai wafatnya pada tahun 224 H. $^{11}$

\section{b. Latar Belakang dan Corak Pemikiran Abu Ubaid.}

Abu Ubaid merupakan seorang ahli hadith (muhaddits) dan juga ahli fiqh (fuqaha) terkemuka dimasa hidupnya. Selama menjabat sebagai qadhi di tarsus, ia sering menangani kasus pertanahan dan perpajakan serta dapat menyelesaikannya dengan baik. Pemikirannya berbeda dengan Abu Yusuf, ia tidak menyinggung tentang masalah kelemahan sistem pemerintahan serta penanggulangannya. Kitab karangannya al Amwal dapat dikatakan lebih kaya dibandingkan dengan kitab al Kharaj dalam hal kelengkapan hadith dan pendapat para sahabat, tabi'in, tabi'it tabi'in. Dalam hal ini, fokus perhatian Abu Ubaid tampaknya lebih tertuju pada permasalahan ynag berkaitan dengan standar etika politik suatu pemerintahan daripada teknik efisiensi pengelolaannya. ${ }^{12}$

\footnotetext{
${ }_{11}^{10}$ Adiwarman Karim, Sejarah Pemikiran Ekonomi Islam, (Jakarta: PT. Raja Grafindo, 2004), 242.

${ }^{11} \mathrm{Ibid}$.

${ }^{12}$ Hans Gottschalk, Abu Ubaid Al Qasim Bin Sallam: Studie Zur Geschicte Der Arabischen Biographie dalam Karim, Sejarah Pemikiran, 243.
} 
Filosofi yang dikembangkan oleh Abu Ubaid bukan merupakan jawaban terhadap berbagai permasalahan sosial, politik, dan ekonomi yang diimplementasikan melalui kebijakan-kebijakan praktis, tetapi hanya merupakan sebuah pendekatan yang bersifat profesional dan teknokrat yang bersandar pada kemampuan teknis. Dengan demikian, tanpa menyimpang dari prinsip keadilan dan masyrakat beradab, pandangan-pandangan Abu Ubaid mengedepankan dominasi intelektualitas Islami yang berakar dari pendekatannya yan bersifat holistic dan teologis terhadap kehidupan manusia di dunia dan akhirat, baik yang bersifat individual maupun sosial. ${ }^{13}$

\section{c. Pandangan Ekonomi Abu Ubaid}

Dalam kitabnya al Amwal tampak bahwa Abu Ubaid menekankan keadilan sebagai prinsip utama. Baginya, jika prinsip keadilan benar-benar diimplementasikan akan membawa kepada kesejahteraan ekonomi dan keselarasan sosial. Pada dasarnya, Abu Ubaid memiliki pendekatan yang berimbang terhadap hak-hak individu, publik, dan negara. Jika kepentingan individu berbenturan dengan kepentingan publik, ia akan berpihak kepada kepentingan publik. Selain itu, tulisan-tulisan Abu Ubaid menitikberatkan pada berbagai persoalan yang berkaitan dengan khalifah dalam mengambil sebuah kebijakan atau wewenangnya dalam memutuskan suatu perkara selama tidak bertentangan dengan ajaran Islam dan kepentingan kaum muslimin. Berdasarkan hal ini, ia menyatakan bahwa zakat tabungan dapat diberikan kepada negara ataupun langsung kepada penerimanya, sedangkan zakat komoditas harus diberikan kepada pemerintah, dan jika tidak, maka kewajiban agama diasumsikan tidak ditunaikan.

Ketika membahas tentang tarif atau presentase untuk kharaj dan jizyah, ia menyinggung tentang pentingnya keseimbangan antara kekuatan finansial penduduk non muslim yang dalam terminologi finansial moderen disebut capacity to pay denga kepentingan dari golongan muslim yang berhak menerimanya. Kaum muslimin dilarang menarik pajak terhadap tanah penduduk non muslim melebihi dari apa yang diperbolehkan dalam perjanjian perdamainan.

Abu Ubaid juga menyatakan bahwa tarif pajak kontraktual tidak dapat dinaikkan, bahkan dapat diturunkan apabila terjadi ketidakmampuan membayar. Lebih jauh ia

\footnotetext{
${ }^{13}$ Karim, Sejarah Pemikiran, 243.
} 
menyatakan bahwa jika seorang penduduk non muslim mengajukan permohonan bebas hutang dan dibenarkan oleh saksi muslim, barang dagangan penduduk non muslim tersebut yang setara dengan jumlah hutangnya akan dibebaskan dari bea cukai (dutyfree). Disamping itu, Abu Ubaid menekankan kepada, disatu sisi, petugas pengumpul kharaj, jizyah, ushur, atau zakat untuk tidak menyiksa masyarakatnya, dan disisi lain, masyarakat agara memenuhi kewajiban finansialnya secara teratur dan sepantasnya. Dengan kata lain Abu Ubaid berupaya untuk menghentikan terjadinya diskriminasi atau favoritisme, penindasan dalam perpajakan serta upaya penghindaran pajak (taz evasion). ${ }^{14}$ Dari sini maka dapat dilihat bahwa Abu Ubaid mengadopsi kaidah fiqh " $l a$ yunkaru taghayyirul fatwa bitaghayyirul azminati" (keberagaman aturan atau hukum karena perbedaan waktu atau periode tidak dapat dielakkan). Namun baginya, kebergaman tersebut dapat sah apabila aturan atau hukum tersebut diputuskan melalui suatu ijtihad.

\section{d. Analisis Terhadap Pemikiran Abu Ubaid}

Abu Ubaid merupakan salah satu tokoh yang paling menekannkan prinsip keadilan sebagai prinsip utama. Menurutnya, jika prinsip keadilan benar-benar diimplementasikan akan membawa kepada kesejahteraan ekonomi dan keselarasan sosial. Pada dasarnya, Abu Ubaid memiliki pendekatan yang berimbang terhadap hakhak individu, publik, dan negara. Jika kepentingan individu berbenturan dengan kepentingan publik, ia akan berpihak kepada kepentingan publik. Karena Abu Ubaid selalu mengedepankan kepentingan publik, sampai-sampai dia memperbolehkan bahwa zakat tabungan dapat diberikan kepada negara ataupun langsung kepada penerimanya, sedangkan zakat komoditas harus diberikan kepada pemerintah, dan jika tidak, maka kewajiban agama diasumsikan tidak ditunaikan.

\section{Yahya bin Umar (213 H)}

\section{a. Biografi Yahya bin Umar}

Yahya bin Umar merupakan salah seorang fuqaha mazhab Maliki. Bernama lengkap Abu Bakar Yahya bin Umar bin Yusuf Al Kannani Al Andalusi, lahir pada tahun 213 H dan dibesarkan di Kordova, Spanyol. Ia berguru kepada para pemuka sahabat Abdullah bin Wahab Al Maliki Ibn Al Qasim, Ibnu Al Kirwan Ramh Abu Al Zhahir bin Al Sarh. Setelah itu pindah ke Hijaz dan berguru kepada Abu Mus'ab Al Zuhri. Akhirnya

${ }^{14}$ Ibid, 253. 
menetap di Qairuwan, Afrika, dan menyempurnakan pendidikannya kepada seorang ahli ilmu faraid dan hisab, Abu Zakariya Yahya bin Sulaiman Al Farisi. ${ }^{15}$

Semasa hidupnya, disamping aktif mengajar, Yahya bin Umar juga aktif menulis. Sehingga banyak menghasilkan banyak karya tulis hingga mencapai 40 juz. Diantara berbagai karyanya yang terkenal adalah kitab al-Muntakhabah fi ikhtisari alMustakhrijah fi al-fiqh al-Maliki dan kitab Ahkam al-Suq.

\section{b. Pemikiran Ekonomi Yahya Bin Umar}

Kitab Ahkam al-Suq yang berasal dari benua Afrika pada abad kedua hijriyah ini merupakan kitab pertama di dunia Islam yang membahas hisbah dan berbagai hukum pasar, satu penyajian materi yang berbeda dari pembahasan-pembahasan fiqih pada umumnya. Salah satu hal yang mempengaruhinya adalah situasi kota Qoiruwan, tempat Yahya bin Umar menghabiskan bagian terpenting dalam hidupnya. Pada saat itu kota Qoiruwan telah memiliki institusi pasar yang permanen sejak $155 \mathrm{H}$ dan para penguasanya, mulai dari Yazid bin Hatim Al Muhibli hingga Ja'far Al Manshur sangat memperhatikan keberadaan institusi pasar.

Menurut Yahya bin Umar, penulisan kitab ini dilatarbelakangi oleh dua persoalan mendasar. Pertama, hukum syara' tentang perbedaan satuan timbangan dan takaran perdagangan dalam satu wilayah. Kedua, hukum syara' tentang harga gandum yang tidak terkendali akibat pemberlakuan liberalisasi harga, sehingga dapat dikhawatirkan dapat menimbulkan kemadlaratan bagi para konsumen.

Dari sini dapat kita lihat bahwa fokus pemikiran Yahya bin Umar tertuju pada hukumhukum pasar yang terefleksikan dalam pembahasan tentang ta'sir (penetapan harga). Menurutnya eksistensi harga merupakan hal yang sangat penting dalam transaksi dan pengabaian terhadapnya akan dapat menimbulkan kerusakan dalam kehidupan masyarakat. Maka ta'sir (penetapan harga) tidak boleh dilakukan, pendapatnya berdasarkan pada beberapa hadith Nabi, antara lain:

Dari Anas bin Malik, ia berkata:"Telah melonjak harga (di pasar) pada masa Rasulullah SAW. Mereka (para sahabat) berkata: "Wahai Rasulullah, tetapkanlah harga bagi kami”. Rasulullah menjawab: "sesungguhnya Allah-lah yang menguasai (harga), yang memberi rezeki, yang memudahkan, dan yang menetapkan harga. Aku

\footnotetext{
${ }^{15}$ Karim, sejarah pemikiran, 261.
} 
sungguh berharap bertemu Allah dan tidak seorangpun (boleh) memintaku untuk melakukan suatu kedzaliman dalam persoalan jiwa dan harta”. (Riwayat Abu Daud) ${ }^{16}$

Dari hadith diatas tampak jelas bahwa Yahya bin Umar melarang kebijakan penetapan harga jika kenaikan harga yang terjadi adalah semata-mata hasil interaksi penawaran dan permintaan yang alami. Dengan kata lain, pemerintah tidak mempunyai hak untuk melakukan intervensi harga. Hal ini akan berbeda jika kenaikan harga diakibatkan oleh ulah manusia (human error). Menurutnya pemerintah hanya dapat mengintervensi harga ketika terjadi aktifitas yang dapat membahayakan kehidupan masyarakat luas. Dalam tersebut, Yahya bin Umar membolehkan pemerintah melakukan intervensi dalam dua hal, yaitu:

1. Pedagang tidak memperdagangkan barang dagangan tertentunya yang sangat dibutuhkan masyarakat, sehingga dapat menimbulkan kemudlaratan serta dapat merusak mekanisme pasar. Dalam hal ini pemerintah dapat mengeluarkan pedagang tersebut dari pasar dan menggantikannya dengan pedagang yang lain berdasarkan kemaslahatan bersama.

2. Pedagang yang melakukan siyasul ighroq atau banting harga (dumping) yang dapat menimbulkan persaingan pasar yang tidak sehat, serta dapat mengacaukan stabilitas harga pasar. Dalam hal ini pemerintah berhak menaikkan kembali harga sesuai harga normal yang berlaku di pasar. Jika menolak, maka pemerintah juga berhak untuk mengusir pedagang tersebut dari pasar.

Jika kita amati pendapat Yahya bin Umar diatas, mengindikasikan bahwa hukum asal intervensi pemerintah adalah haram. Intervensi baru dapat dilakukan apabila stabilitas pasar dan kesejahteraan masyarakat mulai terancam. Hal ini sesuai dengan tugas yang dibebankan kepada pemerintah dalam mewujudkan keadilan sosial masyarakat pada setiap aspek kehidupan masyarakat, termasuk ekonomi.

\section{c. Analisis Terhadap Pemikiran Yahya Bin Umar}

Dari pembahasan di atas, penulisis sedikit mencoba menganalisis pemikiran yang diterapkan oleh Yahya Bin Umar. Pemikiran dari Yahya Bin Umar lebih tertuju pada hukum-hukum pasar yang terefleksikan dalam pembahasan tentang ta'sir (penetapan harga). Menurutnya eksistensi harga merupakan hal yang sangat penting dalam

\footnotetext{
${ }^{16}$ Abu Daud Al Sijistani, Sunan Abu Daud, (t.t: t.p, 1994), 272.
} 
transaksi dan pengabaian terhadapnya akan dapat menimbulkan kerusakan dalam kehidupan masyarakat. Maka ta'sir (penetapan harga) tidak boleh dilakukan. Yahya bin Umar melarang kebijakan penetapan harga jika kenaikan harga yang terjadi adalah semata-mata hasil interaksi penawaran dan permintaan yang alami. Dengan kata lain, pemerintah tidak mempunyai hak untuk melakukan intervensi harga. 


\section{DAFTAR PUSTAKA}

Abu al Husain Muslim bin al Hajjaj al Qusyairi al Naisaburi, Shohih Muslim, Beirut: Darul Fikr, 1993, jilid 2.

Karim. Adiwarman, Sejarah Pemikiran Ekonomi Islam, Jakarta: PT. Raja Grafindo, 2004.

Nasution, Hasyimiyah, 1999, Filsafat Islam, Cet. I, Jakarta: Gajah Mada Press.

Maskawaih, Ibnu, 1999, Menuju Kesempurnaan Akhlak, Cet. IV, Bandung: Mizan.

Syarif , M., 1998, Para Filosof Muslim, Cet. XI , Bandung: Mizan. 